\title{
Torque Expressions and Equivalent Circuits for Salient Pole Synchronous Machines
}

\author{
Minoru Kondo Member (Railway Technical Research Institute)
}

Keywords: salient pole synchronous machine, interior permanent magnet synchronous machine, torque expression, equivalent circuit

Two differetn torque expressions are proposed for salient pole synchronous machines. One expression is the traditional voltagetorque equation.

$$
T=\frac{p}{\omega} \frac{E V}{X_{d}} \sin \delta+\frac{p}{\omega} \frac{V^{2}}{2}\left(\frac{1}{X_{q}}-\frac{1}{X_{d}}\right) \sin 2 \delta
$$

$T$ : Torque; $p$ : number of pole pairs; $\omega$ : angular frequency; $X_{d}$ : d-axis reactance; $X_{q}$ : q-axis reactance; $\delta$ : load angle; $E$ : no-load terminal voltage; $V$ : terminal voltage.

The other expression is a current-torque equation, which has been recently used for permanent-magnet synchronous motors.

$$
T=\frac{p}{\omega} E I_{q}+\frac{p}{\omega}\left(X_{d}-X_{q}\right) I_{d} I_{q}
$$

$I_{d}$ : d-axis current; $I_{q}$ : q-axis current.

Both these expressions have two terms. It has often been stated that the first term in these expressions represents the magnet torque and the second term represent the reluctance torque. However, the corresponding terms in these two expressions do not give the same value when the expressions are used for an interior permanentmagnet synchronous motor (Fig. 1).

The aim of this study is to demonstrate the reason for the abovementioned disagreement. I have obtained two equivalent circuits for this purpose. One is a paralell circuit (Fig. 2.) corresponding to equation (1) and the other is a series circuit (Fig. 3.) correspoiding to equation (2). In the parallel circuit, the current is divided

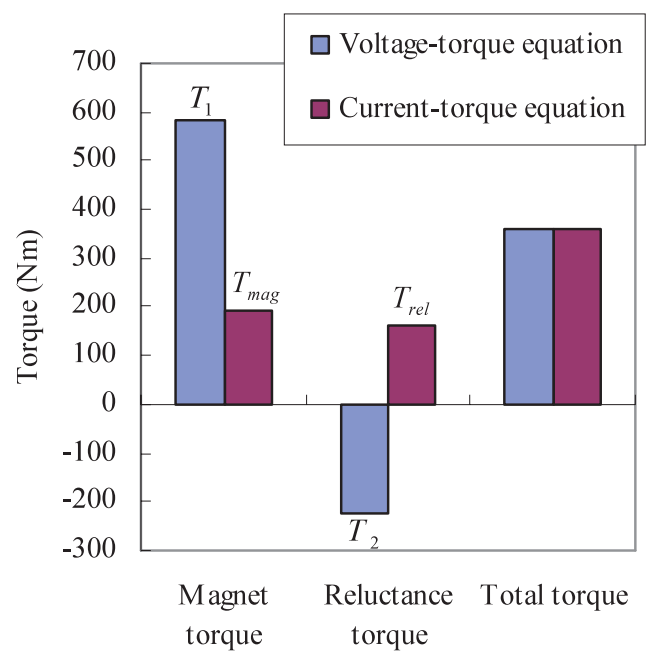

Fig. 1. Evaluation result of torque expressions into three components, whereas in the series circuit the voltage is divided. Therefore, distribution of the active power is different in these two circuits. This is the reason for the above mentioned disagreement.

$$
\begin{aligned}
& \dot{I}=G_{r} \dot{V}-j B_{r} \dot{V}+\dot{I}_{m} \\
& \dot{I}_{m}=j\left(E_{1} / X_{d}\right) e^{j \omega t} \ldots \\
& G_{r}=\frac{\left(X_{d}-X_{q}\right) \sin 2 \delta}{2 X_{d} X_{q}} \\
& B_{r}=\frac{X_{d}+X_{q}-\left(X_{d}-X_{q}\right) \cos 2 \delta}{2 X_{d} X_{q}} \\
& \dot{V}=R_{s} \dot{I}+j X_{s} \dot{I}+\dot{E} \\
& R_{s}=\frac{X_{q}-X_{d}}{2} \sin 2 \beta \\
& X_{s}=\frac{X_{d}+X_{q}}{2}-\frac{X_{d}-X_{q}}{2} \cos 2 \beta \text {. }
\end{aligned}
$$

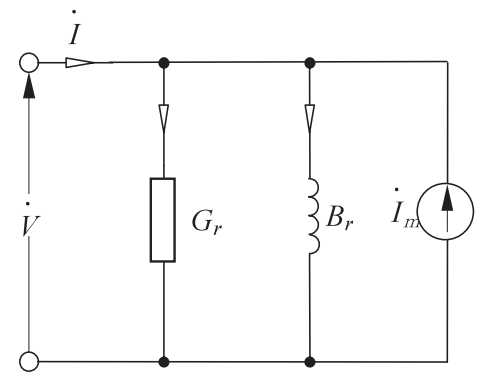

Fig. 2. Equivalent circuit with admittances in paralell

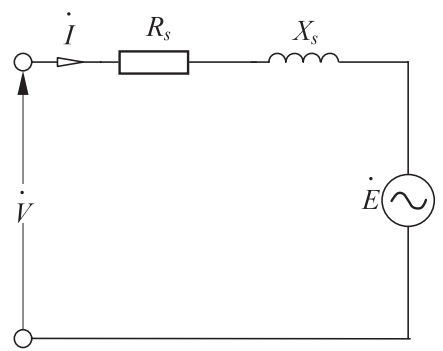

Fig. 3. Equivalent circuit with impedances in series 


\title{
突極同期機のトルク式と等価回路
}

\author{
正員 近藤 稔*
}

\section{Torque Expressions and Equivalent Circuits for Salient Pole Synchronous Machines}

\author{
Minoru Kondo*, Member
}

\begin{abstract}
Two different torque expressions are proposed for salient pole synchronous machines. One is the traditional torquevoltage equation. The other is a torque-current equation and has been recently used for permanent magnet synchronous motors. Both these expressions have two terms. According to a general interpretation, one of the terms represents the magnet torque and the second term represents the reluctance torque. However, the corresponding terms in these two expressions do not give the same value when the expressions are used for an interior permanent-magnet synchronous motor. The aim of this study is to demonstrate this disagreement and identify the reason for the same by using two different equivalent circuits for salient pole synchronous machines.
\end{abstract}

\section{キーワード：突極同期機，永久磁石同期機，トルク式，等価回路}

Keywords: salient pole synchronous machine, interior permanent magnet synchronous machine, torque expression, equivalent circuit

\section{1. はじめに}

永久磁石同期機のトルク式には，二反作用法に基づき $\mathrm{d}$ 軸電流と q 軸電流でトルクを表した式(1) (電流表現のトル ク式と呼ぶ）が用いられている。一方，突極性が生じる設 計がなされた永久磁石同期機は突極同期機の一種でもある が，突極同期機のトルク式には，電圧と負荷角でトルクを 表した式(2)（電圧表現のトルク式と呼ぶ）が従来から用い られている。

これらの理論の基礎となる二反作用法は Brondel が考案

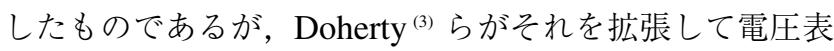
現のトルク式やリラクタンス出力の考え方を導入し, 以後, 同期機の解析法として広く用いられるようになったようで ある。電圧表現の式は Doherty らによって示されたが，電 流表現の式も同時期にLangsdorf ${ }^{(4)} に よ り$ 導出されている。 インバータが登場する前は, 同期機は電圧一定・周波数一 定の電源に接続されて用いられることが普通であり，電圧 表現の方が実用上の利点があったが，永久磁石同期機では 電圧形インバータで電流ベクトルを制御して駆動すること が多いため, 出力ゃトルクを電流の関数として表現する方 が使いやすく，現在では電流表現の式が広く用いられてい るものと考えられる。

これらの式では，回転子の界磁に起因するトルク（永久

\footnotetext{
* (財) 鉄道総合技術研究所

干 185-8540 国分寺市光町 2-8-38

Railway Technical Research Institute

2-8-38, Hikari-cho, Kokubunji 185-8540
}

磁石同期機では磁石トルクと呼ばれる）と突極性に起因す るリラクタンストルクの和としてトルクが表現されている。 しかし，これら 2 つ式を同一電動機の同一運転点に対し て適用したときに，計算されるリラクタンストルクの大き さが全く一致しないことが中村(5)により示されている。

本論文では，この不一致の原因を明らかにするため，2つ の式を比較するとともに，それらの式に対応する等価回路 を示し，トルク式の各項の意味について考察する。

\section{2. 突極同期機のトルク式}

$\langle\mathbf{2} \cdot \mathbf{1}\rangle$ 電流表現のトルク式 永久磁石同期機に対し て良く用いられる電流表現のトルク式は次式で表される ${ }^{(1)}$ 。

$$
T=p\left\{\varphi_{a} I_{q}+\left(L_{d}-L_{q}\right) I_{d} I_{q}\right\}
$$

$T$ : トルク, $p$ : 極対数, $\varphi_{a}$ : 永久磁石による電機 子鎖交磁束, $I_{d}: \mathrm{d}$ 軸電流, $I_{q}: \mathrm{q}$ 軸電流, $L_{d}: \mathrm{d}$ 軸インダクタンス, $L_{q}: \mathrm{q}$ 軸インダクタンス

さらに無負荷誘導起電力を用いた表現にこの式を書き換 えると次式となる。

$$
T=\frac{p}{\omega} E I_{q}+\frac{p}{\omega}\left(X_{d}-X_{q}\right) I_{d} I_{q}
$$

$\omega$ : 角周波数, $E$ : 無負荷誘導起電力 (端子電圧実 効值), $X_{d}: \mathrm{d}$ 軸リアクタンス, $X_{q}: \mathrm{q}$ 軸リアクタ ンス

この式の右辺第 1 項は無負荷誘導起電力に比例しており 永久磁石同期機においては磁石トルクと呼ばれている, そ 


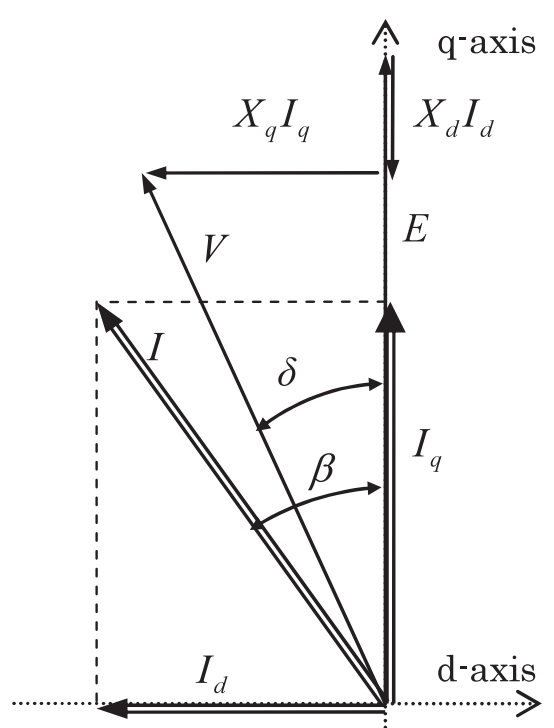

図 1 永久磁石同期機のベクトル図

Fig. 1. Vector diagram of a permanent magnet synchronous machine.

して, 第 2 項は $\mathrm{d}$ 軸と $\mathrm{q}$ 軸のリアクタンスの差に比例して おりリラクタンストルクを表現しているとされている(1)。 以下ではこの第 1 項を $T_{m a g}$, 第 2 項を $T_{r e l}$ とする。

$$
\begin{aligned}
& T_{\text {mag }}=\frac{p}{\omega} E I_{q} \ldots \ldots \ldots \\
& T_{r e l}=\frac{p}{\omega}\left(X_{d}-X_{q}\right) I_{d} I_{q}
\end{aligned}
$$

図 1 に永久磁石同期機のベクトル図を示す。図 1 のベク トル図に示す電流位相角 $\beta$ （電流と無負荷誘導起電力の位 相差）を用いると， d 軸電流， $\mathrm{q}$ 軸電流は次式で表される。

$$
\begin{aligned}
& I_{d}=-I \sin \beta \\
& I_{q}=I \cos \beta
\end{aligned}
$$

\section{$I:$ 電流ベクトルの大きさ}

この関係を用いて (3), (4) 式を書き換えると, 次式となる。

$$
\begin{aligned}
T_{\text {mag }} & =\frac{p}{\omega} E I \cos \beta \ldots \ldots \ldots \ldots \\
T_{\text {rel }} & =\frac{p}{2 \omega}\left(X_{q}-X_{d}\right) I^{2} \sin 2 \beta
\end{aligned}
$$

これらの式から， $T_{\text {mag }}$ は電流位相角に対し正弦波状に変 化し, $T_{r e l}$ はその 2 倍の周波数で正弦波状に変化すること が分かる。

$\langle\mathbf{2} \cdot \mathbf{2}\rangle$ 電圧表現のトルク式 一方, 突極同期機のト ルク式は次式で表される(2)。

$$
T=\frac{p}{\omega}\left\{\frac{3 E_{0 a} V_{a}}{X_{d}} \sin \delta+\frac{3 V_{a}^{2}}{2}\left(\frac{1}{X_{q}}-\frac{1}{X_{d}}\right) \sin 2 \delta\right\}
$$

$E_{0 a}$ ：無負荷誘導起電力 $\left(1\right.$ 相あたり実効値), $V_{a}$ : 相電圧実効値, $\delta$ : 負荷角 (無負荷誘導起電力と電 圧の位相差)
ただし，この式では巻線抵抗や鉄損は無視しており，相 数は 3 相を前提としている。この式をさらに線間電圧を用 いた表現に書き換えると次式となる。

$$
\begin{aligned}
& T=\frac{p}{\omega} \frac{E V}{X_{d}} \sin \delta+\frac{p}{\omega} \frac{V^{2}}{2}\left(\frac{1}{X_{q}}-\frac{1}{X_{d}}\right) \sin 2 \delta \cdots \cdots \\
& V\left(=\sqrt{3} V_{a}\right): \text { 端子電圧実効値 }
\end{aligned}
$$

この式の右辺第 1 項は無負荷誘導起電力に比例する項で あり, 回転子の界磁に起因するトルク（磁石トルク）を表 現している。そして, 右辺第 2 項が $\mathrm{d}$ 軸と $\mathrm{q}$ 軸のリアクタ ンスの差に起因する項であり， $T_{r e l}$ と同様にリラクタンス トルクを表現しているとされている(2)(3)。以下ではこの第 1 項を $T_{1}$, 第 2 項を $T_{2}$ とする。

$$
\begin{aligned}
& T_{1}=\frac{p}{\omega} \frac{E V}{X_{d}} \sin \delta \ldots \ldots \ldots \ldots . . \\
& T_{2}=\frac{p}{\omega} \frac{V^{2}}{2}\left(\frac{1}{X_{q}}-\frac{1}{X_{d}}\right) \sin 2 \delta
\end{aligned}
$$

これらの式から明らかなように， $T_{1}$ は負荷角に対し正弦 波状に変化し, $T_{2}$ はその 2 倍の周波数で正弦波状に変化す る。よって, 電流位相角に対する $T_{m a g}$ や $T_{r e l}$ の特性と同 様に, $T_{1}$ と $T_{2}$ は負荷角に対して変化する。

このように， $T_{1}$ と $T_{\operatorname{mag}}$ はともに界磁によって生じ， $T_{2}$ と $T_{r e l}$ は突極性によって生じ, 電流や電圧の位相角に対す る変化も同じである。よって，一見， $T_{1}$ と $T_{m a g}$, および, $T_{2}$ と $T_{r e l}$ は同じトルクを表現しているように見える。しか し, 一般には, 次章以下で述べるように, それらは全く異 なるトルクを表現している。

\section{3. トルク式の比較}

〈3.1〉 トルク式による計算結果例ここで，2 種類の トルク式を比較するため, 文献(5) に示されている $45 \mathrm{~kW}$ の永久磁石同期機について，それぞれの式を用いてトルク を計算した結果を比較する。

電動機の諸元を表 1 に, 定格点に扔けるトルク計算結果 を図 2 に示す。なお，文献(5)では電動機の卷線抵抗も考 慮しているが, 本論文では簡単化のため巻線抵抗を無視し ている。そのため, 定格電流の值が文献(5) と若干異なっ ている。

図 2 から分かるように電圧表現のトルク式と電流表現の トルク式による全トルクの計算結果は一致し, 以下の関倸 が成立する。

$$
T=T_{1}+T_{2}=T_{\text {mag }}+T_{r e l}
$$

しかし, $T_{1}$ と $T_{m a g}$, および, $T_{2}$ と $T_{r e l}$ の值は一致せず, 全く異なる值となっており， $T_{2}$ と $T_{r e l}$ に関しては正負すら 逆である。永久磁石同期機ではリラクタンストルクを有効 利用するため, 弱め磁束制御を行うのが普通であり, この 電動機の定格点においても弱め磁束制御が行われている想 定である（電流位相角 $\beta$ は $52.8^{\circ}$ )。そして, 実際に電流表 
表 1 電動機の諸元

Table 1. Motor specifications.

\begin{tabular}{|c|c|c|}
\hline Number of pole pair & $p$ & 3 \\
\hline Rated power & $P_{r}$ & $45 \mathrm{~kW}$ \\
\hline Rated rotational speed & $n_{r}$ & $1200 / \mathrm{min}$ \\
\hline Rated torque & $T_{r}$ & $358.1 \mathrm{Nm}$ \\
\hline Rated frequency & $f_{r}$ & $60 \mathrm{~Hz}$ \\
\hline Rated angular frequency & $\omega_{r}$ & $377 \mathrm{rad} / \mathrm{s}$ \\
\hline No-load magneto motive force & $E$ & $339.3 \mathrm{~V}$ \\
\hline d-axis inductance & $L_{d}$ & $4 \mathrm{mH}$ \\
\hline q-axis inductance & $L_{q}$ & $12 \mathrm{mH}$ \\
\hline d-axis reactance & $X_{d}$ & $1.51 \Omega$ \\
\hline q-axis reactance & $X_{q}$ & $4.52 \Omega$ \\
\hline Rated terminal voltage & $V_{r}$ & $380 \mathrm{~V}$ \\
\hline Rated current vector & $I_{r}$ & $119.1 \mathrm{~A}$ \\
\hline Rated phase current & $I_{a}$ & $68.8 \mathrm{~A}$ \\
\hline
\end{tabular}

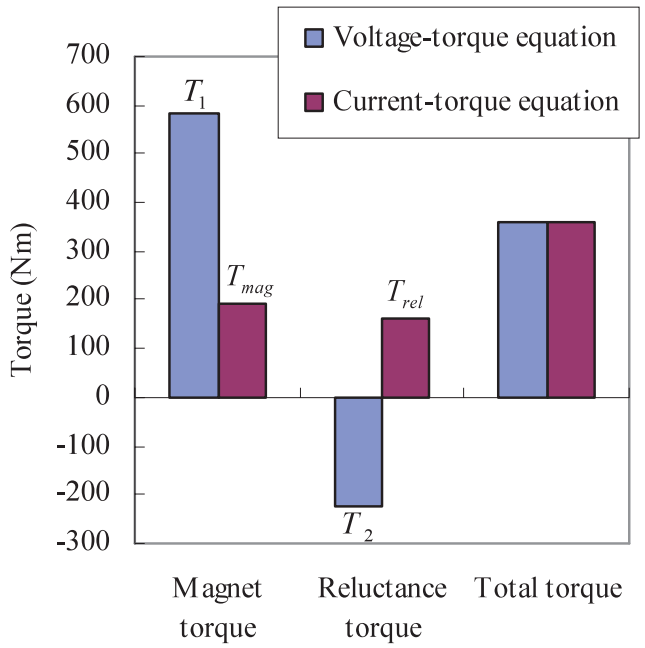

図 2 トルク式による計算結果

Fig. 2. Evaluation result of torque expressions.

現のトルク式におけるリラクタンストルクの值 $T_{r e l}$ は正に なっている。しかし，電圧表現のトルク式におけるリラク タンストルク $T_{2}$ の值は負になっており，これがリラクタ ンストルクだとすると，リラクタンストルクは出力を減じ る方向に作用することになってしまう。以下ではこのよう な不一致が起きる理由について考察する。

まず，トルク特性を比較するため, 文献 (5) の電動機につ いて，電圧を定格電圧に固定した場合の負荷角に対する各 トルク成分の特性を図 3 に，電流を定格電流に固定した場 合の電流位相角に対する特性を図 4 に示す。図 3 と図 4 で は $T_{1}$ と $T_{m a g}$ が負荷角や電流位相角に対して同様に正弦波 状に変化している。一方，図 3 において $T_{2}$ はその 2 倍周 波数で変化しているが， $T_{r e l}$ はそのような変化はしていな い。これに対し，図 4 では， $T_{\text {rel }}$ が 2 倍周波数で変化して いるが， $T_{2}$ はそのような変化はしていない。一般にインダ クタンスの変化は界磁磁束の 2 倍周波数となることからリ

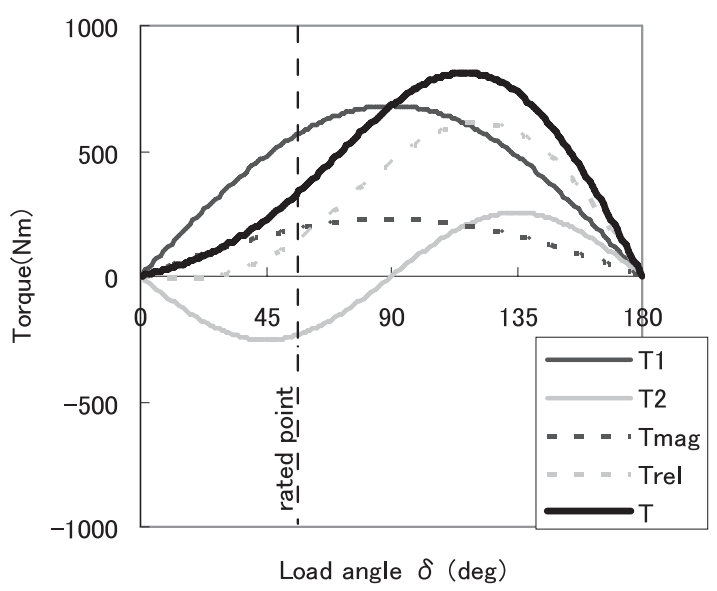

図 3 電圧一定条件でのトルク特性

Fig. 3. Torque characteristics under constant voltage condition.

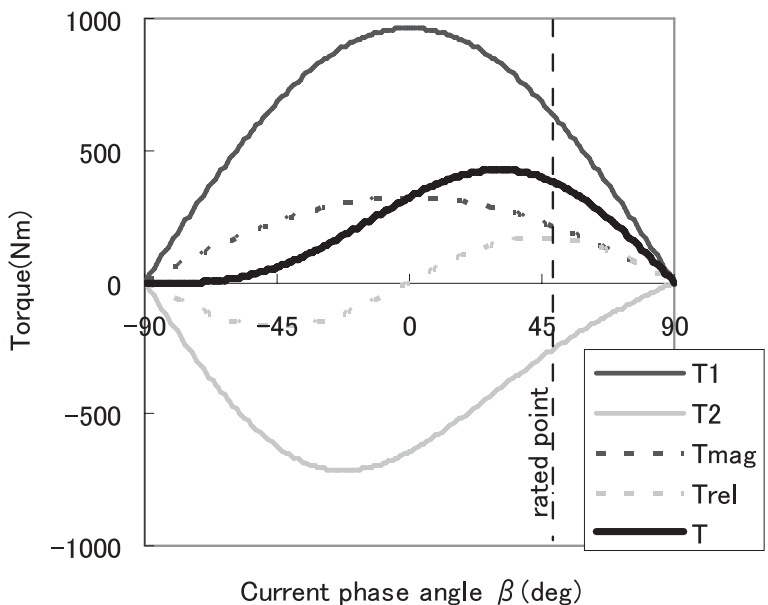

図 4 電流一定条件でのトルク特性

Fig. 4. Torque characteristics under constant current condition.

ラクタンストルクは 2 倍周波数で変化するとされている。 その観点からは, 電圧一定条件下では $T_{2}$ が, 電流一定条件 下では $T_{r e l}$ が，リラクタンストルクの特徵を持ったトルク 特性を有している。

$\langle\mathbf{3 \cdot 2 \rangle}$ 数式表現の比較 次に数式表現の比較により, 2 つの式を比較するため, 電圧表現のトルク式を $\mathrm{dq}$ 軸法に よる表現に変形する。 $\mathrm{d}$ 軸電圧 $V_{d}, \mathrm{q}$ 軸電圧 $V_{q}$ は次式で表 現される。

$$
\begin{aligned}
& V_{d}=-V \sin \delta=-X_{q} I_{q} \\
& V_{q}=V \cos \delta=E+X_{d} I_{d}
\end{aligned}
$$

この関係を用いて (11) 式を変形すると次式が得られる。

$$
T_{1}=\frac{p}{\omega} \frac{E\left(-V_{d}\right)}{X_{d}}=\frac{p}{\omega} \frac{X_{q}}{X_{d}} E I_{q} .
$$

すなわち, $T_{1}$ は $T_{m a g}$ に $X_{q} / X_{d}$ を乗じたものとなっている。 
このことから明らかなように, 突極比が 1 の円筒機では $T_{1}$ と $T_{m a g}$ が一致する。そして, (4), (12) 式から明らかな ように，円筒機では $T_{2}$ と $T_{r e l}$ の值は 0 となる。よって, 2 つのトルク式の間に矛盾は生じない。

さらに，(14)，(15) 式を用いて (12) 式を変形すると次式 が得られる

$$
T_{2}=\frac{p}{\omega}\left(X_{d}-X_{q}\right)\left(\frac{E}{X_{d}}+I_{d}\right) I_{q}
$$

よって, $T_{2}$ は $T_{r e l}$ の式において $\mathrm{d}$ 軸電流 $I_{d}$ に $E / X_{d}$ を加 えたもので $\mathrm{d}$ 軸電流 $I_{d}$ を置き換えた形になっている。

この式から明らかなように，界磁が無く無負荷誘導起電 力 $E$ が 0 となる純粋なリラクタンスモータでは, $T_{2}$ と $T_{r e l}$ は一致する。そして $T_{1}$ と $T_{m a g}$ の值は 0 となる。よって, この場合には，2つのトルク式は矛盾しない。

しかし，式からも明らかなように界磁と突極性が同時に 存在する場合には 2 つトルク式の各項は一致しなくなる。 この関係を式でまとめると以下の通りとなる。

$$
\begin{aligned}
& E=0 \Rightarrow T_{1}=T_{\text {mag }}=0, \quad T_{2}=T_{r e l} \\
& X_{d}=X_{q} \Rightarrow T_{1}=T_{\text {mag }}, \quad T_{2}=T_{r e l}=0 \\
& E \neq 0 \wedge X_{d} \neq X_{q} \Rightarrow T_{1} \neq T_{\text {mag }} \wedge T_{2} \neq T_{\text {rel }}
\end{aligned}
$$

よって，今回問題としている不一致は，トルクを $2 つ の$ 成分に分解する場合にのみ生じる。

この原因についての結論を先に述べると, そもそも, 実 際に発生するトルクは一つであり，それを二つに分解する 際の考え方が異なるためこのような不一致が生じる。具体 的には，電圧 (磁束) を固定して電流を分解することによ りトルクを分解するか, 電流を固定して磁束を分解するこ とでトルクを分解するかの違いに起因して不一致が生じる。 次章ではこのことを説明するため, 等価回路を用いて考察 を行う。

\section{4. 突極同期機の等価回路}

〈4·1〉一般的な等価回路の考え方 一般に回転機を 等価回路で表現する方法としては，有効電力を表現する抵 抗と無効電力を表現するリアクタンス等の回路要素の組み 合わせで表現する方法がある。そして，その場合に，それ らの回路要素を直列に結合して表現する方法と並列に結合 する方法が考えられる。

直列結合の回路においては各要素に流れる電流は同じで あり，各要素で発生する電圧を足し合わせたものが端子電 圧となる。すなわち，この回路は電流を基準として電圧を 有効成分と無効成分に分解する解析方法に対応する。

逆に並列結合の回路では各要素に印加される電圧は同じ であり，各要素を流れる電流を足し合わせたものが相電流 となる。この回路は, 電圧を基準として電流を有効成分と 無効成分に分解する解析方法に対応する。

突極同期機や永久磁石同期機に関しては, 前者の例として,

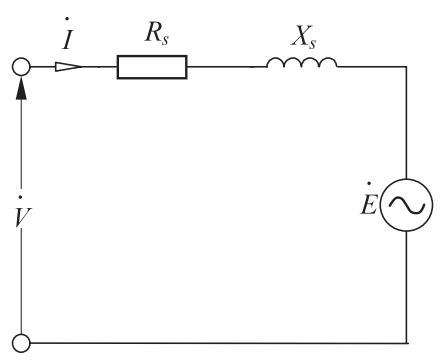

図 5 インピーダンスによる等価回路

Fig. 5. Equivalent circuit composed of impedances in series.

山村 ${ }^{(6)}$ が示したスパイラルベクトル法の特性式, Langsdorf ${ }^{(4)}$ が示した等価インピーダンス, 執行(7) が示した等価回路が あり, 後者の例としてはHonsinger ${ }^{(8)}$ が示したアドミタン ス法による解析がある。そして, 電流表現のトルク式は前 者の回路に対応し, 電圧表現のトルク式は後者の回路に対 応する。以下では，まず，それらの等価回路について示し， 次にトルクの分解について考察する。

$\langle\mathbf{4} \cdot \mathbf{2}\rangle$ 電流基準の等価回路 まず，電流基準の等価 回路に対応する等価インピーダンスを用いた電圧特性式は 次式で表される(6)(7)。

$$
\begin{aligned}
& \dot{V}=R_{s} \dot{I}+j X_{s} \dot{I}+\dot{E} \ldots \ldots \ldots \ldots \\
& R_{s}=\frac{X_{q}-X_{d}}{2} \sin 2 \beta \ldots \ldots \ldots \\
& X_{s}=\frac{X_{d}+X_{q}}{2}-\frac{X_{d}-X_{q}}{2} \cos 2 \beta
\end{aligned}
$$

これに対応する等価回路は図 5 のようになる(7)。なお， 巻線抵抗や鉄損抵抗は簡単のため省略している。

なお，(19)〜(21) 式において， $\dot{V}, \dot{I}, \dot{E}$ は相電圧，相電 流, 相あたりの無負荷誘導起電力のベクトル量であり, 無 負荷誘導起電力を基準にすると時間 $t$ における各ベクトル 量は次式で表される。

$$
\begin{aligned}
& \dot{V}=V_{1} e^{j(\omega t+\delta)} . \\
& \dot{I}=I_{1} e^{j(\omega t+\beta)} \ldots \\
& \dot{E}=E_{1} e^{j \omega t} \ldots
\end{aligned}
$$

ただし， $V_{1}, I_{1}, E_{1}$ は 1 相あたりの電圧，電流，無負荷 誘導起電力のベクトルの大きさである。

この等価回路では, 回転子の界磁によって生じる無負荷 誘導起電力に, 固定子電流によって生じる電機子反作用磁 束による起電力を加えたものが相電圧と等しくなることが 表現されている。

そして出力を等価回路の有効電力から計算すると次式と なり，電流表現のトルク式に対応するものとなっている。

$$
\begin{aligned}
P & =3\left(\operatorname{Re}\left(\dot{E} \dot{I}^{*}\right)+R_{s}|\dot{I}|^{2}\right) \\
& =E I \cos \beta+\frac{X_{q}-X_{d}}{2} I^{2} \sin 2 \beta .
\end{aligned}
$$


$\langle\mathbf{4} \cdot \mathbf{3}\rangle$ 電圧基準の等価回路 電流基準の等価回路は 等価インピーダンスが直列に連なったものとなっていた。 これに対して，特性をアドミタンスの形で表現する解析方 法が Honsinger ${ }^{(8)}$ により示されている。Honsinger が示し たアドミタンスは巻線抵抗や鉄損抵抗も考慮したもので複 雑であるため，ここではそれらの抵抗を０とした式を以下 に示す。

$$
\begin{aligned}
& \dot{I}=G \dot{V}-j B \dot{V} \ldots \ldots \ldots \ldots \ldots \ldots \ldots \ldots \ldots \ldots \ldots \ldots \ldots \ldots \ldots \ldots \\
& \left.G=\frac{\left(X_{d}-X_{q}\right) \sin 2 \delta}{2 X_{d} X_{q}}+\frac{(E / V) \sin \delta}{X_{d}} \ldots \ldots \ldots\right) \cos \delta \\
& X_{d}
\end{aligned}
$$

この表現では界磁による起電力がアドミタンスの中に組 み込まれている。電流基準の等価回路の場合と同様に界磁 による効果を分離しようとした場合，電圧基準の方法にお いては電流を各要素に対応する電流成分に分解するため, 界磁の効果を電圧として表現するのではなく電流として表 現した方が良く，そのような表現方法による永久磁石同期 機の等価回路も存在する ${ }^{(9)(10)}$ 。永久磁石は磁束源というよ りは起磁力源として作用することを考えると，こちらの表 現の方が永久磁石界磁の表現として適切な場合もある。例 えば，この表現であれば $\mathrm{d}$ 軸インダクタンスの飽和により 永久磁石による磁束が変化する効果も考慮することができ ると考えられる。

この表現方法を突極同期機に適用するには，界磁の効果 を次式の電流ベクトルで表現すればよい。この電流べクト ルは三相短絡試験時の短絡電流に相当する。

$$
\dot{I}_{m}=j\left(E_{1} / X_{d}\right) e^{j \omega t}
$$

これを用いると電流特性式は以下のように書くことがで きる。

$$
\begin{aligned}
& \dot{I}=G_{r} \dot{V}-j B_{r} \dot{V}+\dot{I}_{m} \ldots \ldots \ldots \ldots \\
& G_{r}=\frac{\left(X_{d}-X_{q}\right) \sin 2 \delta}{2 X_{d} X_{q}} \ldots \ldots \ldots \ldots \\
& B_{r}=\frac{X_{d}+X_{q}-\left(X_{d}-X_{q}\right) \cos 2 \delta}{2 X_{d} X_{q}}
\end{aligned}
$$

このアドミタンス表現に対応する等価回路表現は要素を 並列接続したものとなり，図 6 のようになる。

そして, 出力をこの回路の有効電力から計算すると次式 となり，電圧表現のトルク式に対応するものになっている。

$$
\begin{aligned}
P & =3\left(\operatorname{Re}\left(\dot{V} \dot{I}_{m}^{*}\right)+G_{r}|\dot{V}|^{2}\right) \\
& =\frac{E V}{X_{d}} \sin \delta+\frac{V^{2}}{2}\left(\frac{1}{X_{q}}-\frac{1}{X_{d}}\right) \sin 2 \delta
\end{aligned}
$$

図 6 の等価回路では回転子の起磁力は $\dot{I}_{m}$ によって打ち

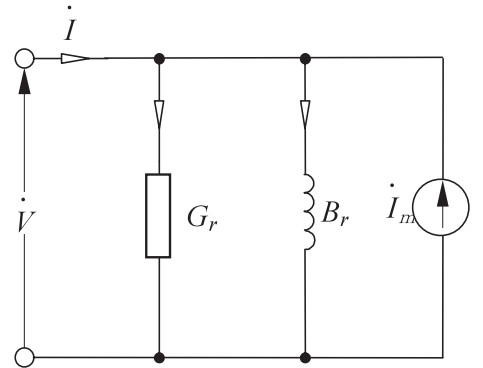

図 6 アドミタンスによる等価回路

Fig. 6. Equivalent circuit composed of admittances in paralell.

消され， $B_{r}$ を流れる励磁電流により同期機が励磁される。 よって, この等価回路は誘導機の $\mathrm{T}$ 形等価回路と類似の考 え方を表現している。

〈4・4〉 トルク式の解釈このように突極同期機の等 価回路としては，インピーダンスを直列に結合して電圧を 各成分に分解する電流基準の表現方法と，アドミタンスを 並列に結合して電流を各成分に分解する電圧基準の表現方 法が可能であり, 電流表現のトルク式は前者に, 電圧表現 のトルク式は後者に対応する。

これらの等価回路や特性式を用いて，トルク式の各成分 の意味を解釈すると以下のようになる。

$T_{m a g}$ ：界磁によって発生する磁束と固定子巻線に流れる 電流によって発生するトルク。図 5 の等価回路において $\dot{E}$ で生じる有効電力に対応する。

$T_{r e l}$ : 突極性の存在により発生する有効磁束と固定子巻線 に流れる電流によって発生するトルク。図 5 の等価回路 中において $R_{S}$ で生じる有効電力に対応する。

$T_{1}$ : 界磁による起磁力を打ち消すように固定子巻線に流 れる電流 $\dot{I}_{m}$ と固定子巻線に鎖交する磁束によって発生す るトルク。図 6 の等価回路において $\dot{I}_{m}$ で生じる有効電 力に対応する。

$T_{2}$ : 突極性により生じる有効電流と固定子巻線に鎖交す る磁束によって発生するトルク。図 6 の等価回路におい て $G_{r}$ で生じる有効電力に対応する。

すなわち，トルクは磁束と電流によって発生すると考え られるが，それを界磁に起因するものと突極性に起因する ものに分解する際に, 磁束を分解するのか電流を分解する かによって，トルクの分解のされ方が異なる。

この相異は考え方の違いに基づくものであり，実験や電 磁界解析によるトルク分離の場合にも発生し得る。例えば, 永久磁石同期機において磁石有り無しの条件でトルクを測 定・解析してトルク分離する場合に, 電流条件を固定する か電圧条件を固定するかによって, 異なる結果が得られる ことが想定される。この相異が，2つのトルク式の相異に 対応すると考えられる。

なお，永久磁石同期機のトルクを考える場合には電流表 現のトルク式による解釈が一般的であるが，堺 (11) らにより 
提案されている永久磁石式リラクタンスモータ (PRM) は 異なった考え方を用いており, 結果的に電圧表現のトルク 式における $T_{1}$ を利用する考え方をしている。

PRM では, 磁石による磁束で $\mathrm{d}$ 軸電流による磁束を打 ち消すように電動機が設計され，完全に打ち消している運 転状態では次式が成り立つ。

$$
I_{d}=-E / X_{d}=-\left|\dot{I}_{m}\right|
$$

この場合には $\mathrm{q}$ 軸電圧が 0 となり負荷角 $\delta$ が $90^{\circ}$ となる。 そして，その際には図 3 に示した様に $T_{2}$ が 0 となり $T_{1}$ が 電圧一定条件下での最大值となる。よって, PRM は $T_{1}$ を 利用する電動機であるといえる。

また，PRMの制御 ${ }^{(12)}$ では，永久磁石を表現する電流成 分 $\dot{I}_{m}$ とそれ以外に電流を分解して制御しており, 制御の点 でもアドミタンスによる等価回路に近い考え方をしている。

$T_{1}$ は式の形からは磁石トルクに相当するようにも見える が，(34) 式が成り立つ場合には(16) 式から次式が得られる。

$$
T_{1}=\frac{p}{\omega} \frac{X_{q}}{X_{d}} E I_{q}=p \frac{X_{q} I_{q}}{\omega} \frac{E}{X_{d}}=-p \Phi_{q} I_{d}
$$

ただし， $\Phi_{q}: \mathrm{q}$ 軸磁束である。

すなわち $T_{1}$ は $\mathrm{q}$ 軸磁束と磁石磁束を打ち消す $\mathrm{d}$ 軸電流 によって発生するトルクであり, 電流表現の考え方におけ るリラクタンストルクのイメージに近いトルク成分である。

このように, 界磁と突極性が同時に存在する場合には, ト ルク式の各項の物理的意味は電圧表現と電流表現のトルク 式において大きく異なる。ところが，それらのトルク式に おいて，第 2 項はいずれもリラクタンストルクと呼ばれて おり，異なる概念が同じ言葉で呼ばれているので注意が必 要である。しかし，ここまでで述べたように，この差異は トルクを分解するときの考え方の差によるものであり，ど ちらかが正しくてどちらかが間違っているというものでは 無く，単純に異なる考え方を表現しているにすぎない。

\section{5. おわりに}

永久磁石同期機のトルク式として用いられている電流表 現のトルク式と, 突極同期機のトルク式として用いられて いる電圧表現のトルク式を，同一電動機の同一運転状態に 適用した場合に，全トルクの磁石トルクとリラクタンスト ルクへの分解が全く異なる結果となる理由を明らかにする ため，双方の式を比較し，考察を加えた。

その結果，両トルク式は全トルクの計算においては常に 一致するが，回転子の界磁と突極性が同時に存在する場合 にトルクを分解する際には不一致が生じることを確認した。 さらに, 等価回路を用いてトルクの分解について考察し, ト ルクを発生する電流と磁束のうち，電流を各成分に分けて 考えるか磁束を各成分に分けて考えるかに起因して，トル ク分解法の違いが生じることを述べた。

本論文は，従来から用いられていた突極同期機のトルク 式と永久磁石同期機のトルク式との間に生じていた矛盾の 原因を説明するものである。本論文が同期機に関わる技術
者の現象理解に役立ち，技術の発展に役立てば幸いである。 (平成 21 年 7 月 29 日受付，平成 21 年 9 月 14 日再受付)

\section{文献}

（1）武田洋次 ·松井信行 ·森本茂雄 ·本田幸雄 : 「埋込磁石同期モー夕の 設計と制御」, p.17, オーム社 (2001)

(2) 電気学会編：「電気学会大学講座 電気機器学」, p.127, オーム社 (2000)

(3) R.E. Doherty and C.A. Nickle: "Synchronous Machines, Part I and II", Trans. A.I.E.E., Vol.45, pp.912-947 (1926)

(4) A.S. Langsdorf: "Theory of Alternating-Current Machinery", pp.447-476, McGRAW-HILL (1937)

(5) M. Nakamura: "A Study of Torque Calculation for PM motor", Toyo Denki Review, Vol.118, pp.1-10 (2008) (in Japanese) 中村雅憲：「PM モータのトルク算定に対する考察」, 東洋電機技報, 第 118 号, pp.1-10 (2008)

（6）山村 昌：「電気回路と回転機の解析と制御一スパイラルベクトル 理論一」, p.111, オーム社 (1998)

（7）執行岩根：「電気機械設計論 3」, p.641, 丸善 (1951)

(8) V.B. Honsinger: "Performance of Polyphase Permanent Magnet Machines", IEEE Trans. Power Apparatus and Systems, Vol.PAS-99, No.4, pp.15101516 (1980)

(9) T. Sebastian, G.R. Slemon, and M.A. Rahman: "Modelling of Permanent magnet Synchronous Motors", IEEE Trans. Magnetics, Vol.MAG-22, No.5, pp.1069-1071 (1986)

(10) B.A. Welchko, T.M. Jahns, W.L. Soong, and J.M. Nagashima: "IPM Synchronous Machine Drive Response to Symmetrical and Asymmetrical Short Circuit Fault", IEEE Trans. Energy Conversion, Vol.18, No.2, pp.291-298 (2003)

11) K. Sakai, N. Takahashi, E. Shimomura, M. Arata, Y. Nakazawa, and T Tajima: "Development of Permanent Magnet Reluctance Motor Suitable for Variable-Speed Drive for Electric Vehicle", IEEJ Trans. IA, Vol.123, No.6, pp.681-688 (2003-6) (in Japanese)

堺 和人 · 高橋則雄 - 霜村英二 · 新 政憲 - 中沢洋介 - 田島敏伸 : 「可変速特性に優れた電気自動車用永久磁石式リラクタンスモー夕 の開発」, 電学論 D, 123, 6, pp.681-688 (2003-6)

(12) Y. Nakazawa, R. Kurosawa, K. Sakai, and M. Arata: "A Flux Weakening Control for Permanent Magnet Reluctance Motor", 2000 National Convention Record, IEE Japan, No.4-140 (2003) (in Japanese)

中沢洋介・黒沢良一・堺 和人・新 政憲：「永久磁石式リラク夕 ンスモータの弱め磁束制御」, 平成 12 年電気学会全国大会, No.4-140 (2003)

\section{付 録}

1. 等価インピーダンスおよび等価アドミタンスの導出 本論文中で紹介している等価回路に対応する表現式 (19)〜 (21) および (26)～(28) の導出方法について述べる。

まず，(22) 式を変形し，(5)，(6)，(14)，(15)，(23)，(24) 式を用いると

$$
\begin{aligned}
\dot{V} & =V_{1} e^{j(\omega t+\delta)}=(V / \sqrt{3}) e^{j \delta} e^{j \omega t} \\
& =(V \cos \delta+j V \sin \delta)\left(e^{j \omega t} / \sqrt{3}\right) \\
& =\left(E+X_{d} I_{d}+j X_{q} I_{q}\right)\left(e^{j \omega t} / \sqrt{3}\right) \\
& =\left\{E+\left(-X_{d} \sin \beta+j X_{q} \cos \beta\right) I\right\}\left(e^{j \omega t} / \sqrt{3}\right) \\
& =\dot{E}+\left(-X_{d} \sin \beta+j X_{q} \cos \beta\right) e^{-j \beta} \dot{I}
\end{aligned}
$$

と変形できる。

ここで, 電流ベクトルの係数部分を取り出して変形すると 
$\left(-X_{d} \sin \beta+j X_{q} \cos \beta\right) e^{-j \beta}$

$$
\begin{aligned}
& =\left(-X_{d} \frac{e^{j \beta}-e^{-j \beta}}{j 2}+j X_{q} \frac{e^{j \beta}+e^{-j \beta}}{2}\right) e^{-j \beta} \\
& =j X_{d} \frac{1-e^{-j 2 \beta}}{2}+j X_{q} \frac{1+e^{-j 2 \beta}}{2} \\
& =j \frac{X_{d}+X_{q}}{2}+j \frac{X_{q}-X_{d}}{2} e^{-j 2 \beta} \\
& =\frac{X_{q}-X_{d}}{2} \sin 2 \beta+j\left(\frac{X_{d}+X_{q}}{2}-\frac{X_{d}-X_{q}}{2} \cos 2 \beta\right) \\
& =R_{s}+j X_{s} \ldots \ldots \ldots \ldots \ldots \ldots \ldots \ldots \ldots \ldots \ldots \text { (付 }
\end{aligned}
$$

となり，等価インピーダンス表現が得られる。

同様に, (23) 式を変形し, (5), (6), (14), (15), (22), (24), (29) 式を用いると,

$$
\begin{aligned}
\dot{I} & =I_{1} e^{j(\omega t+\beta)}=(I / \sqrt{3}) e^{j \beta} e^{j \omega t} \\
& =(I \cos \beta+j I \sin \beta)\left(e^{j \omega t} / \sqrt{3}\right) \\
& =\left(I_{q}-j I_{d}\right)\left(e^{j \omega t} / \sqrt{3}\right) \\
& =\left(-\frac{V_{d}}{X_{q}}-j \frac{V_{q}-E}{X_{d}}\right)\left(e^{j \omega t} / \sqrt{3}\right) \\
& =\left\{j \frac{E}{X_{d}}+\left(\frac{V \sin \delta}{X_{q}}-j \frac{V \cos \delta}{X_{d}}\right)\right\}\left(e^{j \omega t} / \sqrt{3}\right) \\
& =\dot{I}_{m}+\left(\frac{\sin \delta}{X_{q}}-j \frac{\cos \delta}{X_{d}}\right) e^{-j \delta} \dot{V} \ldots \ldots \ldots \ldots
\end{aligned}
$$

ここで, 電圧ベクトルの係数部分を取り出して変形すると

$$
\begin{aligned}
& \left(\frac{\sin \delta}{X_{q}}-j \frac{\cos \delta}{X_{d}}\right) e^{-j \delta} \\
& =\left(\frac{e^{j \delta}-e^{-j \delta}}{j 2 X_{q}}-j \frac{e^{j \delta}+e^{-j \delta}}{2 X_{d}}\right) e^{-j \delta} \\
& =-j \frac{1-e^{-j 2 \delta}}{2 X_{q}}-j \frac{1+e^{-j 2 \delta}}{2 X_{d}} \\
& =-j\left(\frac{X_{d}+X_{q}}{2 X_{d} X_{q}}\right)-j\left(\frac{X_{q}-X_{d}}{2 X_{d} X_{q}}\right) e^{-j 2 \delta} \\
& =\frac{X_{d}-X_{q}}{2 X_{d} X_{q}} \sin 2 \delta-j \frac{X_{d}+X_{q}-\left(X_{d}-X_{q}\right) \cos 2 \delta}{2 X_{d} X_{q}} \\
& =G_{r}-j B_{r}
\end{aligned}
$$

となり，等価アドミタンス表現が得られる。

近 藤 稔 (正員) 1972 年 8 月 18 日生。1997 年 3 月東京大

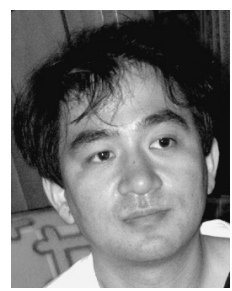
学大学院機械工学専攻修士課程修了。現在, (財) 鉄道総合技術研究所にて鉄道車両の駆動用電動機 の研究開発に従事。工学博士。

と変形できる。 